\title{
CYTOGENETIC ANALYSIS OF THE EFFECTS OF EPINEPHRINE ON CULTURED HUMAN
} LYMPHOCYTES

\author{
DJELIĆ N*, DJELIĆ DIJANA*, SPREMO-POTPAREVIĆ BILJANA**, MARKOVIĆ BILJANA* and \\ ŽIVKOVIĆ LADA** \\ * Faculty of Veterinary Medicine, University of Belgrade, \\ ** Faculty of Pharmacy, University of Belgrade \\ (Received 2. February, 2003)
}

Epinephrine can modulate mitotic activity of normal and malignant cells and exhibit genotoxic potential in some test-systems. It is assumed that metabolic conversion of phenolic groups in the catechol ring of epinephrine leads to the formation of reactive derivatives and superoxide anions, capable of damaging cellular molecules including DNA. The aim of the present study was to evaluate the cytotoxic and genotoxic effects of epinephrine on human peripheral blood lymphocytes in vitro. The lowest concentration of epinephrine used in these experiments $\left(5 \times 10^{-10} \mathrm{M}\right)$ was calculated to be in the range of the physiological blood level of epinephrine in humans. Three experimental concentrations corresponded to minimal $\left(2 \times 10^{-7} \mathrm{M}\right)$, average $\left(10^{-6} \mathrm{M}\right)$ and maximal $\left(5 \times 10^{-6} \mathrm{M}\right)$ therapeutic doses in human medicine. In addition, the highest concentrations exceeded the maximal therapeutic dose 10fold $\left(5 \times 10^{-5} \mathrm{M}\right)$ and 30 -fold $\left(1.5 \times 10^{-4} \mathrm{M}\right)$, respectively. On the basis of the results obtained it can be concluded that epinephrine had no influence on the appearance of chromosome aberrations under the described experimental conditions. However, mitotic index was significantly lower in cultures treated with the three highest concentrations of epinephrine used in this investigation.

Key words: cancer, epinephrine, genotoxicity, mitotic index

\section{INTRODUCTION}

Epinephrine has been called the hormone of "fight or flight" due to its immediate release under the influence of various stressors. Moreover, there is increasing evidence that stress hormones and neurotransmitters may represent a link between the immune, endocrine and central nervous systems. The physiological effects of epinephrine prepare the body for extraordinary physical and mental exertion. At the biochemical level, specific binding of epinephrine to adrenergic receptors coupled to heterotrimeric glycoproteins (G-proteins) initiates a cascade of biochemical and molecular responses inside the cell leading to changes in cellular activity (Sanders, 1995). 
Epinephrine has the highest affinity for -adrenoceptors. Binding of epinephrine fo -adrenoceptors activates $\mathrm{G}_{\mathrm{s}}$ to stimulate adenylate cyclase. Pharmacological and stereochemical investigations revealed that the aromatic catechol moiety of epinephrine is essential for its agonist activity (Main and Tucker, 1985).

Although data in the literature concerning physiological and biochemical changes under the influence of epinephrine and other catecholamines in various mammalian tissues are very abundant, possible genotoxic and mutagenic effects have been evaluated only in a few studies. Thus, McGregor et al. (1988) examined the mutagenicity of catecholamines (including epinephrine) in the mouse lymphoma L5178Y cell assay. Although, according to their results, epinephrine expressed some mutagenic potential, it is still not clear whether these results can be confirmed in other test-systems on mammalian cells.

There are some interesting experimental data that dopamine causes substantial DNA damage manifested mainly by strand breaks and base modifications (Graham et al., 1978; Moldeus et al., 1983). This effect is probably caused by dopamine oxidative metabolites. Namely, it is conceivable that oxidation of dopamine phenolic groups results in the formation of superoxide anions. This hypothesis is supported by the finding that induction by L-dopamine of DNA strand breaks in human fibroblasts was inhibited by coincubation with superoxide dismutase (SOD) (Moldeus et al., 1983).

The aim of the present study was to evaluate mitotic activity and possible cytogenetic changes in cultured human lymphocytes treated with a wide range of epinephrine concentrations. Experimental concentrations of epinephrine were calculated to correspond the human physiological blood level, the therapeutic range, and up to 30 -fold greater than the therapeutic concentration. Thus, the results of this investigation should contribute to a better understanding of the genetic risk at a wide range of epinephrine concentrations.

\section{MATERIALS AND METHODS}

Test substance and controls. Epinephrine (CAS No., Adrenalin, Jugoremedija, Zrenjanin) was used as the test substance. An acetone solution of N-methyl$\mathrm{N}^{\prime}$-nitro-N-nitrosoguanidine (MNNG) (Sigma Chemical Co., St. Louis, MO) at a final concentration of $10^{-6} \mathrm{M}$ and human recombinant insulin (Inutral HM-100, ICN Galenika) at concentration $10^{-8} \mathrm{M}$, were the positive controls. The negative control was prepared as a placebo in Jugoremedija (Zrenjanin) as a solution of all compounds in the preparation except the active one-epinephrine.

Lymphocyte culture. Human peripheral blood lymphocyte cultures were prepared according to a slight modification of the protocol described by Evans and O'Riordan (1975). Heparinised whole blood samples $(0.8 \mathrm{ml})$ obtained from three healthy men under 35 years of age were added to vials with $9.2 \mathrm{ml}$ of prewarmed Parker 199 medium (Torlak, Belgrade, Yugoslavia) containing 30\% of inactivated calf serum (Serva, Heidelberg, Germany) and $0.04 \mathrm{mg} / \mathrm{ml}$ of phytohaemagglutinin (Murex Diagnostics Ltd., Dartford, England). Cultures were incubated in the dark for $72 \mathrm{~h}$ at $370.5^{\circ} \mathrm{C}$. 
Treatment. In order to determine experimental concentrations of epinephrine comparable to the blood level of epinephrine in treated patients, we consulted a textbook on pharmacology (Reynolds, 1996). Exactly $47 \mathrm{~h}$ and $30 \mathrm{~min}$ after the beginning of incubation, epinephrine (Adrenalin, Jugoremedija) was added to cultivation vials in such amounts to obtain final experimental concentrations of: $5 \times 10^{-10} \mathrm{M}, 2 \times 10^{-7} \mathrm{M}, 10^{-6} \mathrm{M}, 5 \times 10^{-6} \mathrm{M} .5 \times 10^{-5} \mathrm{M}$ and $1.5 \times 10^{-4} \mathrm{M}$. Positive and negative control substances were added to separate cultivation vials.

Chromosome preparation and analysis. Two hours before harvesting, colcemid (Ciba, Basel, Switzerland) was added to the cultures to achieve a final concentration of $0.5 \mathrm{~g} / \mathrm{ml}$. After standard chromosome preparation microscopic slides were stained in $10 \%$ Giemsa (Kemika, Zagreb) solution in Gurr buffer (pH 6.8). Mitotic index was determined on 1000 or more cells, whereas the chromosome aberrations were analysed on 150 metaphase spreads per experimental concentration.

In addition to the cytogenetic study, we evaluated the cytotoxic or cytostatic effects of epinephrine on cultured human lymphocytes on the same microsopic slides.

Statistical analysis. The obtained data are presented as mean SE. The statistical significance of differences between control and treated groups was analysed by Student's $t$-test.

\section{RESULTS}

The results of the analysis ot mitotic activity in cultures treated with epinephrine are presented in Table 1. The control values of Ml were $5.98 \%$ for untreated cultures and $5.91 \%$ in cultures treated with negative control (the solvent). Epinephrine did not change the mitotic index (MI) significantly at the lower concentrations $\left(5 \times 10^{-10} \mathrm{M}, 2 \times 10^{-7} \mathrm{M}\right.$ and $\left.10^{-6} \mathrm{M}\right)$. However, at higher concentrations of epinephrine there was a significant decrease in MI. In cultures with a final concentration of epinephrine of $5 \times 10^{-6} \mathrm{M}$, MI was lowered to $3.6 \%(p<0.05)$, while the concentration of $5 \times 10^{-5} \mathrm{M}$ had a more profound effect decreasing $\mathrm{Ml}$ by $55 \%$ to the value of $2.7 \%$. Finally, at the highest experimental concentration epinephrine $\left(1.5 \times 10^{-4} \mathrm{M}\right)$ decreased $\mathrm{Ml}$ by nearly $70 \%$ in comparison to untreated cultures $(\mathrm{Ml}=1.9 \%, \mathrm{p}<0.01)$. As expected, the positive controls also changed mitotic activity: the well known mutagen MNNG lowered MI to $3.4 \%(p<0.01)$, whereas insulin elevated $\mathrm{MI}$ to $8.9 \%(p<0.01)$.

The results of cytogenetic analysis are presented in Table 2. For the sake of precise comparisons, we analysed exactly 150 mitotic figures for each experimental point in control and treated cultures. Evidently, epinephrine did not influence the frequencies of observed chromosomal changes significantly. Only N-methyl$\mathrm{N}$-nitro-N-nitrosogunaidine (MNNG) caused a significant increase of numeric chromosome aberrations (aneuploidies and polyploidies), as well as chromosomal gaps and breaks indicating structural changes. The genotoxic effect of MNNG was most profound here as $15.3 \%$ of observed cells contained gaps and breaks. As usual, the frequency of aneuploid cells was higher than both the frequency of 
polyploid cells and cells with chromosomal gaps and breaks, probably due to the unavoidable loss of chromosomes during the preparation of metaphase spreads.

Table 1. Influence of epinephrine on mitotic index of cultured human lymphocytes

\begin{tabular}{|c|c|c|c|}
\hline Treatment & $\begin{array}{c}\text { Number of cells } \\
\text { observed }\end{array}$ & $\begin{array}{c}\text { Mitotic index } \\
(\%)\end{array}$ & $\begin{array}{l}\text { Percentage of } \\
\text { control value }\end{array}$ \\
\hline Untreated & 2224 & 5.98 & 100.00 \\
\hline Negative control (solvent) & 2133 & 5.91 & 98.83 \\
\hline $10^{-6} \mathrm{M}$ MNNG & 2056 & $3.36^{\star \star}$ & $59.20 * *$ \\
\hline $10^{-8} \mathrm{M}$ insulin & 2570 & $8.95^{\star \star}$ & $149.67^{\star \star}$ \\
\hline Epinephrine $5 \times 10^{-10} \mathrm{M}$ & 2011 & 4.87 & 81.44 \\
\hline Epinephrine $2 \times 10^{-7} \mathrm{M}$ & 2298 & 5.05 & 84.45 \\
\hline Epinephrine $10^{-6} \mathrm{M}$ & 2478 & 5.69 & 95.15 \\
\hline Epinephrine $5 \times 10^{-6} \mathrm{M}$ & 2331 & $3.60^{*}$ & $60.20 *$ \\
\hline Epinephrine $5 \times 10^{-5} \mathrm{M}$ & 2060 & $2.67^{\star \star}$ & $44.65^{\star \star}$ \\
\hline Epinephrine $1.5 \times 10^{-4} \mathrm{M}$ & 1828 & $1.86^{\star *}$ & $31.10 * *$ \\
\hline
\end{tabular}

MNNG- N-methyl-N'-nitro-N-nitrosoguanidine; ${ }^{*} \mathrm{p}<0.05 ;{ }^{*} \mathrm{p}<0.01$; (Student's $t$-test)

Table 2. Chromosome aberration frequencies in cultured human lymphocytes treated with epinephrine

\begin{tabular}{|c|c|c|c|c|c|c|c|}
\hline Treatment & $\begin{array}{l}\text { Number of } \\
\text { cells } \\
\text { observed }\end{array}$ & \multicolumn{2}{|c|}{$\begin{array}{c}\text { Aneuploidies } \\
\text { No }(\%)\end{array}$} & \multicolumn{2}{|c|}{$\begin{array}{l}\text { Polyploidies } \\
\text { No (\%) }\end{array}$} & \multicolumn{2}{|c|}{$\begin{array}{c}\text { Gaps and } \\
\text { breaks } \\
\text { No } \quad(\%)\end{array}$} \\
\hline Untreated & 150 & 4 & 2.67 & 1 & 0.67 & 4 & 2.67 \\
\hline Negative control (solvent) & 150 & 6 & 4.00 & 3 & 2.00 & 2 & 1.33 \\
\hline $10^{-6} \mathrm{M}$ MNNG & 150 & 13 & $8.67^{*}$ & 7 & $4.67^{\star}$ & 23 & $15.33^{\star \star *}$ \\
\hline $10-8 \mathrm{M}$ insulin & 150 & 5 & 3.33 & 0 & 0.00 & 1 & 0.67 \\
\hline Epinephrine $5 \times 10^{-10} \mathrm{M}$ & 150 & 5 & 3.33 & 1 & 0.67 & 2 & 1.33 \\
\hline Epinephrine $2 \times 10^{-7} \mathrm{M}$ & 150 & 7 & 4.67 & 2 & 1.33 & 3 & 2.00 \\
\hline Epinephrine $10^{-6} \mathrm{M}$ & 150 & 4 & 2.67 & 0 & 0.00 & 1 & 0.67 \\
\hline Epinephrine $5 \times 10^{-6} \mathrm{M}$ & 150 & 5 & 3.33 & 0 & 0.00 & 4 & 2.67 \\
\hline Epinephrine $5 \times 10^{-5} \mathrm{M}$ & 150 & 8 & 5.33 & 1 & 0.67 & 3 & 2.00 \\
\hline Epinephrine $1.5 \times 10^{-4} \mathrm{M}$ & 150 & 7 & 4.67 & 3 & 2.00 & 3 & 2.00 \\
\hline
\end{tabular}

MNNG- N-methyl-N'-nitro-N-nitrosoguanidine; ${ }^{*} \mathrm{p}<0.05 ;{ }^{* * *} \mathrm{p}<0.001 ;$ (Student's $t$-test) 


\section{DISCUSSION}

In the last two decades it has been clearly demonstrated that some hormones can exhibit genotoxic and mutagenic effects. Since early epidemiological investigations have shown a correlation between the prolonged use of steroid hormones and cancer (Goh, 1967), it is not surprising that steroid hormones are the best studied group. Basic mechanisms underlying the mutagenic action of natural and synthetic estrogens have been revealed. Interestingly, metabolic conversion of estrogens leads to the formation of reactive oxygen species and intermediates capable of covalently damaging DNA (Liehr, 2001). Therefore, estrogens are considered as complete carcinogens acting both as tumor promoters (increasing cell proliferation) and tumor initiators (increasing the mutation rate) (Winter and Liehr, 1996).

Despite progress in understanding the molecular mechanisms of estrogen mutagenesis, data about genotoxicologic effects of nonsteroid hormones and mediators are scarce. Since hormones are normal compounds in animal and human bodies, little attention has been paid to their significance in mutation processes (Djelić, 1997).

In this investigation we evaluated the genotoxic and cytotoxic potential of epinephrine on human lymphocytes in vitro. Bearing in mind that human $\mathrm{T}$ and $\mathrm{B}$ lymphocytes contain -adrenoceptors in the plasma membrane (van Tits et al., 1990), we assumed that after binding of epinephrine to -adrenoceptors signal transduction may contribute to modulation of mitotic activity and/or the appearance of chromosomal changes.

The analysis of chromosome breakage and aberrations in this investigation, showed that epinephrine had no influence on this cytogenetic manifestation of mutagenic action. Although McGregor et al. (1988) observed some mutagenic action of epinephrine on mouse lymphoma L5178Y cells, they used a test for gene mutations at the thymidine kinase locus. Namely, despite this mutagenic potential of epinephrine at the gene level, the effects may be undetectable at a cytogenetic level.

Metabolic oxidation of phenolic groups of catecholamines is considered as a keystep in their genotoxic action. Reactive intermediary semiquinone radicals from dopamine cause oxidative damage to cellular components, while quinones can react with nucleophilic groups in proteins and DNA (Mason, 1979). On the other hand, free oxygen species are created during the oxidation of catechol groups, such as the superoxide anion $\left(\mathrm{O}_{2}^{-}\right)$. Superoxide anions appear to cause chromosome breakage and sister-chromatid exchanges in human lymphocytes in vitro (Emerit et al., 1982). The abscence of a genotoxic effect at the cytogenetic level in this study may reflect the relatively weak metabolic capacity of lymphocytes with respect to catecholamines.

To determine possible cytotoxic or cytostatic effects of epinephrine, we analysed mitotic index (MI) for each experimental concentration as well as for controls. The positive control (MNNG) decreased MI by $40 \%$, compared to untreated cultures, possibly due to arrest of mitosis because of repair of genetic material. 
Additionally, in cells with a relatively high level of genetic damage cytotoxic effects occur.

Human recombinant insulin at a concentration of $10^{-8} \mathrm{M}$ was used as the positive control capable to stimulate cultured lymphocyte proliferation (Djelić and Soldatović, 1997). It should be mentioned that insulin has expressed a maximal effect at the same or very similar concentrations in a number of studies. For example, insulin increased malic enzyme gene expression at $0.4 \times 10^{-8} \mathrm{M}$ in rat differentiating brown adipocytes (Garcia-Jiminez et al., 1993), maximally stimulates DNA synthesis in mouse embryonic fibroblastic 3T3-F442A preadipose cells at $0.5 \times 10^{-8}$ $M$ (Tang et al., 1995), and rapidly decreases the amount of IGF-1-binding protein mRNA in human HepG2 cells at $10^{-8} \mathrm{M}$.

The available data suggest that the epinephrine-induced increase in intracellular cAMP can modulate mitotic activtiy of various cell types. Intracellular CAMP concentrations increase transiently prior to DNA synthesis in such different cells as bacteria, yeasts and mammalian cells (Bronstad et al., 1983). Hormonespecific stimulation of adenylate cyclase elevates intracellular cAMP in regenerating rat liver hepatocytes (Boynton and Whitfeld, 1981). Moreover, the growth response of hepatocytes is facilitated by -adrenergic stimulation and subsequent increase of cAMP inside the cell (Friedman et al., 1981). However, some experimental findings indicate that CAMP has dual effects on hepatocyte proliferation stimulative effects early in the prereplicative period $\left(G_{0}\right.$ and early $\left.G_{1}\right)$, and a marked inhibition after the transition from $G_{1}$ to $S$ phase ( Sand et al., 1992). It is worth noting that during hepatocarcinogenesis -adrenoceptors increase in number and responsiveness to isoproterenol (Refsnes et al., 1986).

The interference of lymphocyte proliferation obtained in cultures treated with high concentrations of epinephrine is in accordance with the observation that stimulation of -adrenoceptors accompanied by elevated intracellular CAMP concentration suppresses lymphocyte proliferation (Bourne et al., 1974; Dell'Orco et al., 1977). Moreover, Cook and McCormick (1993) have shown that CAMP interferes with mitogenic signal transduction in Rat1 cells. Likewise, cAMP inhibits growth in soft agar of mouse lung tumour cell lines (Droms, 1996).

Therefore, according to available data, CAMP can act both as a stimulator and an inhibitor of mitogenesis, depending on the cell type or phase of the cell cy$c l e$. In the present study epinephrine inhibited lymphocyte proliferation $(p<0.05)$ at the concentration $5 \times 10^{-6} \mathrm{M}$, which is comparable to the maximal therapeutic dose in human medicine. At concentrations of $5 \times 10^{-5} \mathrm{M}$ and $1.5 \times 10^{-4} \mathrm{M}$ the inhibition was more profound $(p<0.01)$, and greater than the cytotoxic effects of the positive control.

In light of the experimental data obtained in this study it can be concluded that epinephrine did not exhibit genotoxic effects. However, high experimental concentrations of epinephrine interfere with lymphocyte proliferation in vitro.

Acknowledgments: This research was supported by the Serbian Ministry for Science, Technologies and Development, grant 1873. We are grateful to "Jugoremedia" (Zrenjanin) for preparation of the negative control (placebo). 
Acta Veterinaria (Beograd), Vol. 53. No. 2-3, 113-120, 2003.

Address for correspondence:

Dr. Ninoslav Đelić

Faculty of Veterinary Medicine

Bul. JNA 18, 11000 Belgrade,

Serbia \& Montenegro

\section{REFERENCES}

1. Bourne HR, Lichtenstein TM, Melman KL, Henney CS, Weinstein Y, Shearer GM, 1974, Modulation of inflammation and immunity by cyclic AMP. Science, 184, 19-28.

2. Boynton AL, Whitfield J, 1981, Calmodulin and cyclic AMP-dependent protein kinases mediate calcium-induced stimulation of DNA synthesis by rat liver cells. Advanc Cyclic Nucl Res, 14, 411-19.

3. Bronstad GO, Sand T, Christoffersen T, 1983, Bidirectional concentration-dependent effects of glucagon and dibutyryl cyclic AMP on DNA synthesis in cultured rat hepatocytes. Biochim Biophys Acta, 763, 58-63.

4. Cook SJ, McCormick F, 1993, Inhibition by cAMP of Ras-dependent activation of Ra,. Science, 262, 1069-72.

5. Dell'Orco TR, Martin J, Douglas WH, 1977, Cyclic AMP and serum arrest of the mitotic activity of human diploid fibroblasts, In Vitro, 13, 55-62.

6. Djelić N, Soldatović B, 1998, Mitotic activity and cell cycle kinetics in cultures of human lymphocytes treated with insulin. Genetika, 30, 125-31.

7. Djelić N, 1997, Cytogenetic effects of estradiol, thyroxine, insulin and epinephrine on human lymphocytes in vitro. PhD thesis, Faculty of Biology, University of Belgrade.

8. Droms KA, 1996, -adrenergic signalling in neoplastic lung type 2 cells: glucocorticoid-dependent and -independent defects, $B r J$ Cancer, 74, 432-8.

9. Emerit l., Keck M, Levy A, Feingold J, Michelson AM, 1982, Activated oxygen species as the origin of chromosome breakage and sister-chromatid exchanges, Mutat Res, 103, 165-72.

10. Evans HJ, O'Riordan M, 1975, Human peripheral blood lymphocytes for the analysis of chromosome aberrations in mutagen tests, Mutat Res, 31, 135-48.

11. Friedman DL, Claus TH, Pilkins SJ, Pine GE, 1981, Hormonal regulation of DNA synthesis in primary cultures of adult rat hepatocytes, Exp Cell Res. 135, 283-90.

12. Goh KO, 1967, Chromosomal breaks in women taking birth control pills. USAEC-ORAU Res Report, 106, 97-104.

13. Graham DJ, Tiffany SM, Bell WR, Gutknecht WF, 1978, Autooxidation versus covalent binding of quinones as the mechanism of toxicity of dopamine, 6-hydroxydopamine, and related compounds toward c1300 neuroblastoma cells in vitro, Mol Pharmacol. 14, 644-53.

14. Liehr JG, 2001, Genotoxicity of the steroidal oestrogens oestrone and oestradiol: possible mechanism of uterine and mammary cancer development, Human Reprod Update, 7, $273-81$.

15. Main BG, Tucker H. 1985, Recent advances in -adrenergic blocking agents, Prog Med Chem, 22, $122-64$.

16. Mason RP, 1979, Free radical metabolites of foreign compounds and their toxicological significance, In: Hodgson E, Bend JR, Philpot RM, editors, Reviews in Biochemical Toxicology, Amsterdam, Elsevier, North-Holland, 151-200.

17. McGregor D, Riach CG, Brown A, Edwards I, Reynolds D, West K, Willington S, 1988, Reactivity of catecholamines and related substances in the mouse lymphoma L5178Y cell assay for mutagens, Environ Mol Mutagen, 11, 523-44.

18. Moldeus P., Nordenskjold M., Bolcsfoldi G, 1983, Genetic toxicity of dopamin, Mutat Res., 124: 923.

19. Refsnes M, Sager G, Sanders D, Sand TE, Jacobsen S, Christoffersen T, 1986, Increased number of -adrenoceptors in hepatocytes from rats treated with 2-acetylaminofluorene, Cancer Res, 46, 2285-8. 
20. Reynolds JEF, editor. 1996, The Extra Pharmacopoeia. $30^{\text {th }}$ Ed. London, The Pharmaceutical Society; 1996. pp 1238-40.

21. Sand T, Thoresen GH, Refsnes M, Christoffersen T, 1992, Growth-regulatory effects of glucagon, insulin, and epidermal growth factor in cultured hepatocytes. Temporal aspects and evidence for bidirectional control by cyclic AMP. Dig Dis Sci, 37, 84-92.

22. Sanders VM, 1995, The role of adrenoceptor-mediated signals in the modulation of lymphocyte function. Adv Neuroimmunol, 5, 283-98.

23. van Tits LJH, Michel MC, Grokss-Wilde H, Happel M, Eigler FW, Soliman A et al. 1990, Catecholamines increase lymphocyte 2-adrenergic receptors via a 2-adrenergic spleen dependent process. Am J Physiol, 258, E191-E202.

24. Winter M, Liehr JG, 1996, Possible mechanism of induction of benign prostatic hyperplasia by estradiol and dihydrotestosterone in dogs. Toxicol Appl Pharmacol, 136, 211-19.

\title{
CITOGENETIČKA ANALIZA DEJSTVA ADRENALINA NA HUMANE LIMFOCITE U KULTURI
}

\author{
DJELIĆ N, DJELIĆ DIJANA, SPREMO-POTPAREVIĆ BILJANA, MARKOVIĆ BILJANA i \\ ŽIVKOVIĆ LADA
}

\section{SADRŽAJ}

Adrenalin može da promeni mitotsku aktivnost normalnih i malignih ćelija. Pored toga, adrenalin ispoljava genotoksične efekte u nekim test-sistemima. Smatra se da metabolička konverzija fenolnih grupa u kateholnom prstenu adrenalina dovodi do stvaranja reaktivnih derivata i superoksidnih anjona sposobnih da oštete molekule u ćeliji, uključujući DNK. Cilj ovog istraživanja bio je da se izvrši evaluacija citotoksičnih $\mathrm{i}$ genotoksičnih efakata adrenalina na limfocite periferne krvi čoveka in vitro. Najniža eksperimentalna koncentracija adrenalina korišćena u ovom eksperimentu $\left(5 \times 10^{-10} \mathrm{M}\right)$ proračunata je tako da bude uporedljiva sa fiziološkom koncentracijom adrenalina u krvi čoveka. Tri eksperimentalne koncentracije odgovaraju minimalnim $\left(2 \times 10^{-7} \mathrm{M}\right)$, srednjim $\left(10^{-6} \mathrm{M}\right)$ i maksimalnim $\left(5 \times 10^{-6} \mathrm{M}\right)$ terapijskim dozama u humanoj medicini. Pored toga, dve najviše koncentracije veće su od maksimalne terapijske doze deset $\left(5 \times 10^{-5} \mathrm{M}\right)$ i trideset puta $\left(1.5 \times 10^{-4} \mathrm{M}\right)$. Na osnovu dobijenih rezultata može se zaključiti da adrenalin nije značajno uticao na pojavu hromozomskih aberacija pod opisanim eksperimentalnim uslovima. Međutim, tri najviše koncentracije adrenalina upotrebljene u ovom eksperimentu dovode do značajnog smanjenja mitotske aktivnosti. 